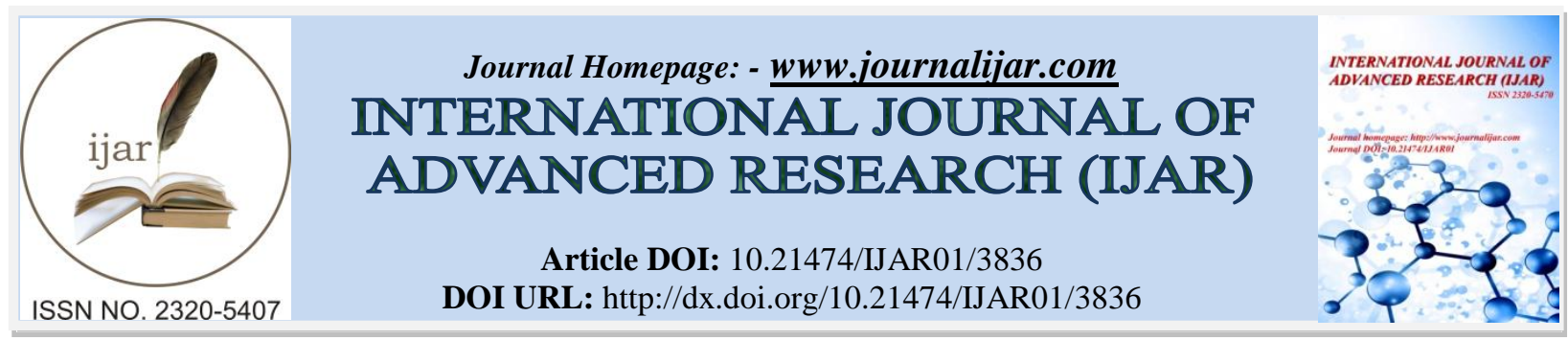

RESEARCH ARTICLE

\title{
FLOW AND MECHANICAL CHARACTERISTICS OF BRICK BATS SELF COMPACTING CONCRETE.
}

\author{
Aman Kumar ${ }^{1}$ and Jitu Kujurb ${ }^{2}$. \\ 1. M.E. Student, Civil \& Environmental Engineering, BIT, Mesra, Ranchi (Jharkhand) \\ 2. Assistant Professor, Civil \& Environmental Engineering, BIT, Mesra, Ranchi (Jharkhand)
}

\section{Manuscript Info}

Manuscript History

Received: 01 February 2017

Final Accepted: 03 March 2017

Published: April 2017

\begin{abstract}
Concrete is most widely used construction materials in the world. Properly designed, mixed, compacted and cured concrete leads to durability problem. Self-compacting concrete is a better option to conventional compacting concrete for the places where the normal way of compacting may not be very much useful because of different site condition. Self-compacting concrete or high performance concrete is an innovative concrete mix which did not require any kind of vibration for compaction and placing. Hardened SSC concrete is dense, homogeneous and has the same mechanical properties and durability as conventional concrete. The utilization of waste industrial product in the concrete industry (i.e. flyash, rice husk ash slag etc.) is very much needed for the protection of our environment. Brick bat is one of the waste materials obtained from construction industry may be used in concrete as an alternative to coarse aggregate. In this paper, an experimental work has been carried out to study the flow characteristics of SCC concrete made with OPC 43 grade, W/C is 0.4 and $27 \%$ fly-ash with brick bats as replacement of coarse aggregate with different percentage (i.e. $0 \%, 5 \%, 10 \%, 15 \%, 20 \%, 25 \%$ and $30 \%$ ) through different methods (i.e. mini slump cone, $\mathrm{L}$ box test, $\mathrm{V}$ funnel and $\mathrm{V}$ funnel $\mathrm{T}_{5 \text { min. }}$ ). From the results it is observed that slum flow of SSC made with $20 \%$ replacement of brick bats is within the acceptable limit. It is also observed that the compressive strength of SSC concrete made with 20 percent replacement of brickbats is almost equal to that made with control mix.
\end{abstract}

Copy Right, IJAR, 2017,. All rights reserved.

\section{Introduction:-}

Concrete technology had under gone different level of study in the enhancement of mechanical properties and durability from 80's onwards [1]. Till 1980 the research study was only concentrated to enhancing strength of concrete, but other properties like durability did not draw lot of attention of the concrete technologists [1]. Selfcompacting concrete is best level of engineered concrete with a higher range of fluidity without segregation and is capable of filling form work under its own weight only (Okamura 1997) [1]. Thus we can say that SSC is a kind of new generation concrete which not only eliminate the need of vibration but also reduces the conventional W/C ratio. 
These kind of concrete was first developed in Japan[2] in $80^{\mathrm{s}}$ to combat the deterioration of concrete grade due to unavailability of skilled labors, along with this problems at the corners of formwork regarding the homogeneity and compaction of cast in place concrete mainly with intricate structures so as to improve the durability of concrete and structures.

Self-compacting concrete (SCC) is a kind of concrete that does not require any kind of compaction either manual or with vibration machine for compaction and placing. This is able to flow under its own weight, completely filling formwork and getting a high degree of compaction, even in the presence of heavy and congestion reinforcement. Hardened concrete is dense, homogeneous and has the same mechanical behavior and durability as traditional compacted concrete.

Because of industrialization there is huge amount of fly-ash, ceramic waste, rice husk etc. are generated and causing threat to environment. The utilization of this waste industrial product in the concrete industry is very much needed for the protection of our environment. So to reduce problem of these construction waste, the work had been undertaken so that this can be used for construction work. The use of waste material for the construction in such a way is very much necessary so that the construction work can be made economical as well as environment friendly. . Now we move forward in this kind of study, we study flow characteristics as well as the mechanical behavior of SSC with partial replacement of coarse aggregate by brick bates. This kind of study has resulted in the development of self-compacting concrete (SCC) with the replacement of natural coarse aggregate with the some construction site waste, it is a very much needed revolution in the field of construction. Therefore in this paper, the study of selfcompacting concrete has been done on concrete which is made with OPC 43 grade cement, brick bats and w/c $=0.38$.

\section{Experimental Work:-}

\section{Material used:-}

For the preparation of SCC mix, OPC 43grade cement conforming to IS 8112 (1989)[3] and brick bats of size 20 $\mathrm{mm}$ and specific gravity equal to 2.51 were used. Fine aggregate conforming to zone II as per IS 383[4] was used to prepare the SCC mix. Fine aggregate and coarse aggregates were used of specific gravity 2.56 and 2.63 respectively. Mix proportion are obtained for M40 mix as per modified NANSU[2] method are given in Table 1.

Table 1:- Mix proportion.

\begin{tabular}{|c|c|}
\hline Material & Quantity \\
\hline Cement & $394.28 \mathrm{~kg} / \mathrm{m} 3$ \\
\hline FLYASH & $110.2 \mathrm{~kg} / \mathrm{m} 3$ \\
\hline Fine aggregate & $883.3 \mathrm{~kg} / \mathrm{m} 3$ \\
\hline Coarse aggregate & $670 \mathrm{~kg} / \mathrm{m} 3$ \\
\hline Water & 191.7 lit. \\
\hline Superplastisizer & $0.6 \%$ by weight of cement \\
\hline VMA & $0.12 \%$ by weight of cement \\
\hline
\end{tabular}

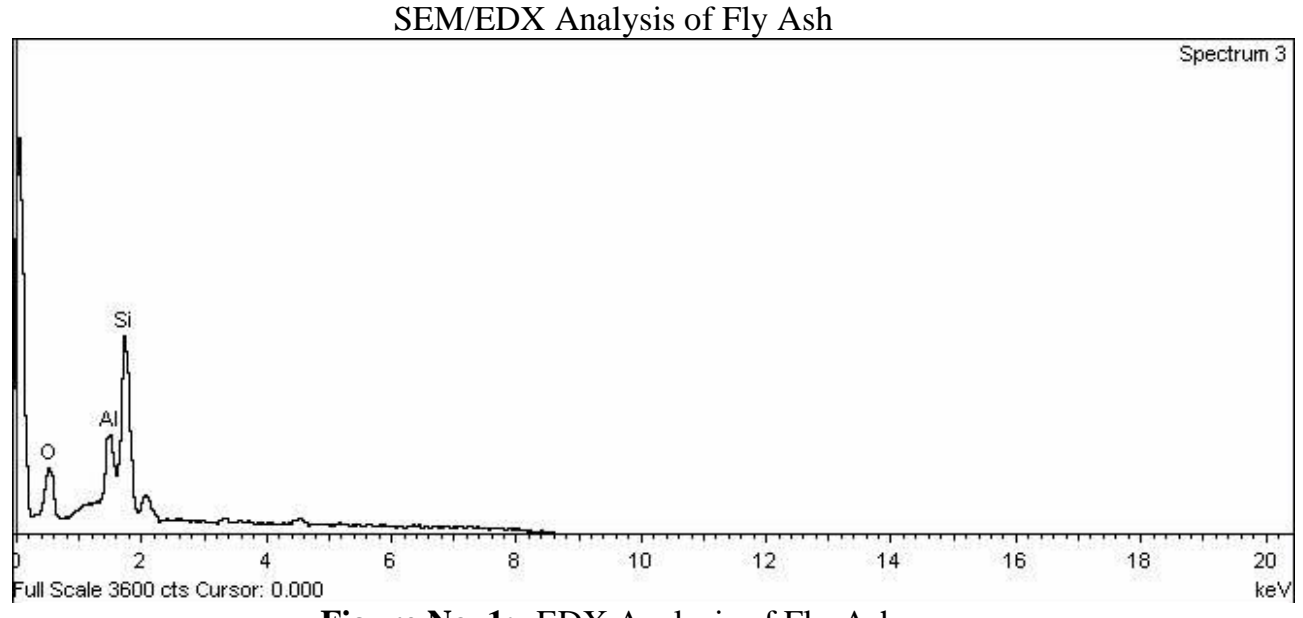

Figure No. 1:- EDX Analysis of Fly-Ash. 


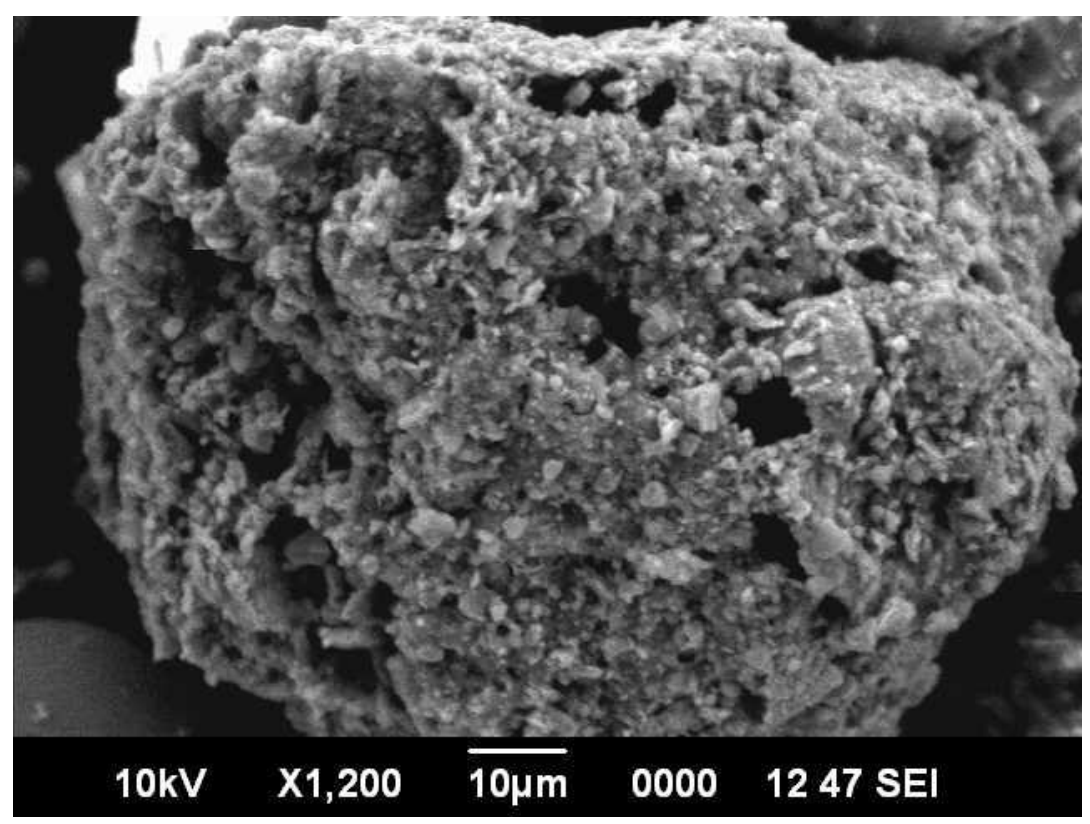

Figure No. 2:- SEM Image of Fly-Ash

SEM image of Fly-ash is shown in figure no 2. Surface characteristics of fly ash can be study from SEM image, as per the figure no.2 surface of fly ash is rough with significant number of voids and almost spherical in shape. From EDX analysis which is shown in figure number 1, silica content is shown in higher percentage.

\section{Preparation of SCC concrete and flow tests:-}

Concrete proportioning is done using OPC, Flyash and brick bats as replacement of coarse aggregate with different percentage i.e. $0 \%, 5 \%, 10 \%, 15 \%, 20 \%, 25 \%$ and $30 \%$. A chemical admixture (Auramix 400 \& AuramixV100) is used in the mix. Slump flow was measured using different types of testing methods. Water cement ratio (W/C) is taken as per conventional concrete. Optimum dosage of super plasticizer is calculated by Marsh Cone test by keeping the VMA dosage is constant at $0.12 \%$.

In slump flow test (Mini slump cone), the slump flow is used to assess the horizontal flow of SCC in the absence of any kind of obstructions. The Mould in the shape of a truncated cone with the internal diameter $200 \mathrm{~mm}$ at the base, $100 \mathrm{~mm}$ diameter at the top and 300mm height, as specified and confirming to EN12350-2[5 and 6]. The diameter of slump is measured in two perpendicular diagonal direction and is tabulated in table no 3.

Using L BOX test, the flow of the concrete was also measured. The vertical section is filled with concrete, and then the gate lifted to let the concrete flow into the horizontal section. When the flow has stopped, the height of the concrete at the end of the horizontal section is expressed as a proportion of that remaining in the vertical section. European federation dedicated to specialist construction chemicals and concrete (EFNARC)[6] have proposed Specifications and guidelines for Self Compacting Concrete and acceptance values for different test are presented in table 2. The described V-funnel test is used to determine the filling ability (flow ability) of the concrete with a maximum aggregate size of $20 \mathrm{~mm}$. The described $\mathrm{V}$-funnel test is used to determine the filling ability (flow ability) of the concrete with a maximum aggregate size of $20 \mathrm{~mm}$. The funnel is filled with about 12 liter of concrete and the time taken for it to flow through the apparatus measured. Another method is V Funnel $\mathrm{T}_{5}$ is also similar as the Vfunnel test. This test is conducted for checking the segregation. After filling the funnel with about 12 liter of concrete left it for 5 minutes then allowed to flow and time taken by the concrete to segregate was noted down. 
Table 2:- Typical range of test result.

\begin{tabular}{|c|c|c|c|c|c|}
\hline \multirow[t]{2}{*}{ SL NO. } & \multirow[t]{2}{*}{ METHOD } & \multirow[t]{2}{*}{ PROPERTY } & \multirow[t]{2}{*}{ UNIT } & \multicolumn{2}{|c|}{ TYPICAL RANGE VALUES } \\
\hline & & & & Min & Max \\
\hline 1 & Slump flow test & Filling ability & $\mathrm{mm}$ & 650 & 800 \\
\hline 2 & $\mathrm{~T}_{50 \mathrm{~cm}}$ slump flow & Filling ability & $\mathrm{Sec}$ & 2 & 5 \\
\hline 3 & J-ring & Passing ability & $\mathrm{mm}$ & 0 & 10 \\
\hline 4 & V-funnel & Filling ability & $\mathrm{Sec}$ & 8 & 13 \\
\hline 5 & $\mathrm{~V}$-funnel at $\mathrm{T}_{5}$ minutes & $\begin{array}{l}\text { Segregation } \\
\text { resistance }\end{array}$ & $\mathrm{Sec}$ & 8 & 15 \\
\hline 6 & L-box & Passing ability & ratio & 0.8 & 1.0 \\
\hline 7 & U-box & Passing ability & $\mathrm{mm}$ & 0 & 30 \\
\hline 8 & Fill box & Passing ability & $\%$ & 90 & 100 \\
\hline 9 & GTM screen stability & $\begin{array}{l}\text { Segregation } \\
\text { resistance }\end{array}$ & $\%$ & 0 & 15 \\
\hline 10 & Orimet & Filling ability & $\mathrm{Sec}$ & 0 & 5 \\
\hline
\end{tabular}

\section{Result And Disscuasion:-}

The flow test result as shown in table 3 by different method is clearly indicating that as we goes on replacing the coarse aggregate by brick bates the flow characteristic of the slump changes. The replacement of only $5 \%$ coarse aggregate changes the slump flow from $732 \mathrm{~mm}$ to $713 \mathrm{~mm}$.but if author observe other flow result there is no such impact like slump flow, $\mathrm{V}$-funnel $\mathrm{T}_{5}$ change in the time of flow by only $0.2 \mathrm{sec}$ and slump $\mathrm{T}_{50}$ is also increase by only $0.2 \mathrm{sec}$ and along with this author can see that blocking ratio is also same 0.9 .

Table 3:- Flow result.

\begin{tabular}{|c|c|c|c|c|c|}
\hline $\begin{array}{c}\text { Percentage of Brick } \\
\text { bates }\end{array}$ & $\begin{array}{c}\text { Slump } \\
\text { flow } \\
(\mathrm{mm})\end{array}$ & $\begin{array}{c}\text { Slump } \\
\text { Test } \mathrm{T}_{50} \\
(\mathrm{sec})\end{array}$ & $\begin{array}{c}\mathrm{V}- \\
\text { funnel } \\
\text { flow time sec }\end{array}$ & $\begin{array}{c}\mathrm{V} \text { - funnel } \\
\mathrm{T}_{5 \text { min. }} \\
\text { time in sec. }\end{array}$ & $\begin{array}{c}\mathrm{L}-\text { box } \\
\text { Blocking ratio }\end{array}$ \\
\hline 0 & 732 & 4.3 & 08.6 & 12.2 & 0.9 \\
\hline 5 & 713 & 4.5 & 09.2 & 12.4 & 0.9 \\
\hline 10 & 704 & 4.9 & 09.3 & 13.6 & 0.9 \\
\hline 15 & 701 & 5.3 & 09.7 & 13.6 & 0.8 \\
\hline 20 & 710 & 5.7 & 09.9 & 14.4 & 0.8 \\
\hline 25 & 695 & 6.3 & 11.1 & 15.1 & 0.8 \\
\hline 30 & 680 & 11.9 & 17.1 & 0.8 \\
\hline
\end{tabular}

But as author goes on replacing the coarse aggregate than after $20 \%$ replacement it was observe that there is a significant change in all the flow test result as shown in table 3. 


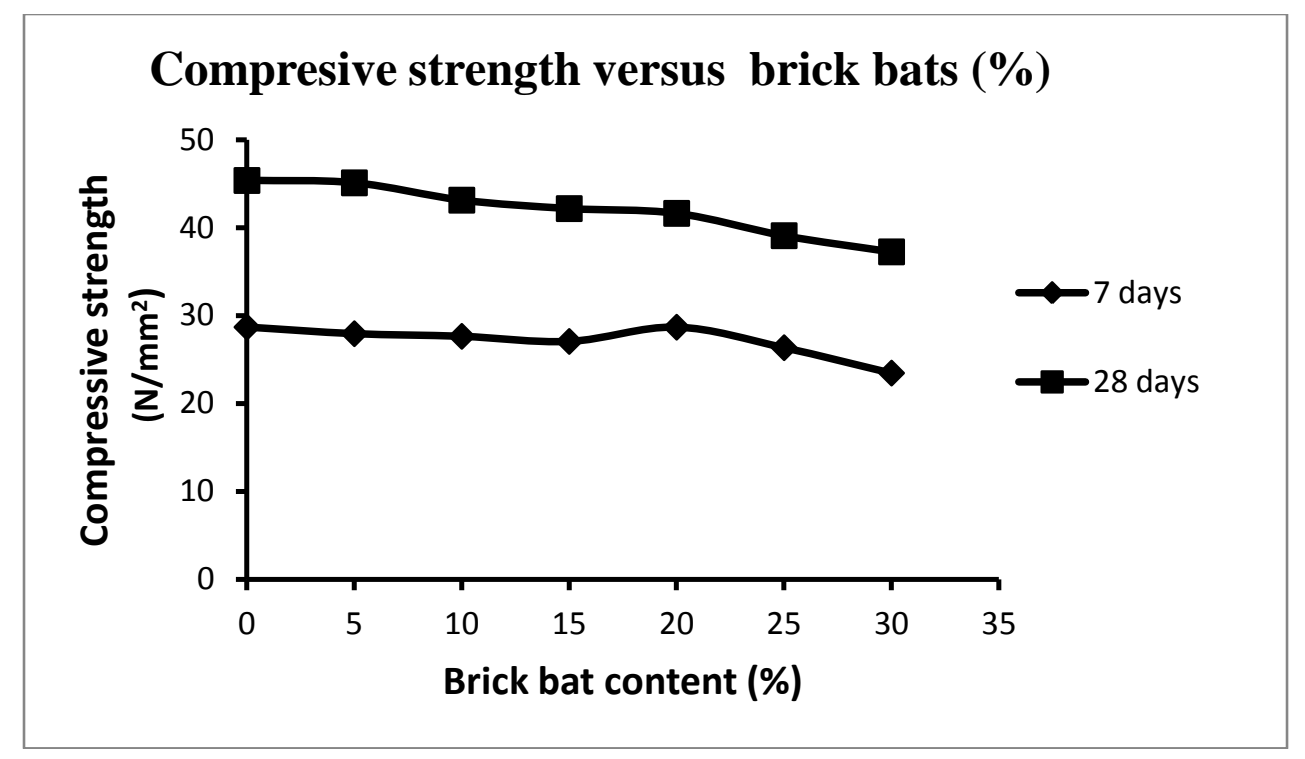

Table 4:- Compressive Strength Result.

\begin{tabular}{|c|c|c|c|}
\hline S1. no & $\begin{array}{c}\text { Replacement of Brick } \\
\text { bates (\%) }\end{array}$ & \multicolumn{2}{|c|}{ Compressive strength } \\
\cline { 3 - 4 } & & $\begin{array}{c}\text { After 7 days curing } \\
\text { N/mm }\end{array}$ & $\begin{array}{c}\text { After 28 days curing } \\
\text { N/mm }\end{array}$ \\
\hline 1 & 00 & 28.68 & 45.36 \\
\hline 2 & 05 & 27.93 & 45.09 \\
\hline 3 & 10 & 27.63 & 43.12 \\
\hline 4 & 15 & 27.05 & 42.16 \\
\hline 5 & 20 & 28.67 & 41.62 \\
\hline 6 & 25 & 26.34 & 39.08 \\
\hline 7 & 30 & 23.45 & 37.24 \\
\hline
\end{tabular}

When author compare the flow result with the compressive strength then also it was observe that there is no significant change with $5 \%$ replacement of coarse aggregate but after $20 \%$ replacement a sudden loss in compressive strength can observed.

The result shown in table 3 and table 4 author observed that upto 20\% replacement of coarse aggregate can be done. For self-compacting concrete both flow and strength parameter is very much necessary to maintain. If flow parameter is not maintain properly than this concrete becomes a normal or conventional concrete and the benefit of SCC is lost.

For the above mention set of result in table 3 and table 4 authors are going to compare both parameter simultaneously than it was observed that with $5 \%$ replacement did not bring a major change in strength parameter but slump flow decrease by $19 \mathrm{~mm}$, but even after this decrease the flow value is within the limit so author goes on replacing the coarse aggregate $10 \%, 15 \%, 20 \%, 25 \%, 30 \%$. Up to $20 \%$ it was observe from the result that slump flow decrease with every percentage increase in replacement but even after this decrease in flow rate and strength parameter both the characteristic are within the limit so even after $20 \%$ also, than replace coarse aggregate by $25 \%$, now it was observe that both the parameter not only fall outside the limit but also a sudden change in all parameter of flow test can be observe.

So from above dissuasion author conclude that upto $20 \%$ replacement of coarse aggregate with the brick bates can be done.

\section{Conclusion and Future Work:-}

From the above result of flow test and compressive strength author conclude that up to $20 \%$ replacement can be done which is within the different parameter as shown in table 2. In this study author observe that with increase in percentage of brick bats the flow parameter decrease this is because of the water absorption by brick bats is much 
higher than the coarse aggregate and fine aggregate even the brick bats use in SSD condition. Further this study can be done with different cement and different durability test such as carbonation test, permeability test, water absorption test can be study.

\section{Reference:-}

1. Cement and Concrete Research, Vol. 31, No. 3, Mar. 2001, pp. 413-420.

2. H Okamura and M Ouchi. 'Self-compacting Concrete. Development, Present use and Future'. Proceedingd of the First International RILEM Symposium on 'Self-Compacting Concrete'. Sweden, Proc 7, 1999, pp 3-14.

3. H Okamura and M Ouches Self-compacting Concrete Journal of advanced concrete technology vol1, No.1, 515, April 2003 @ Japan concrete institute

4. IS 8112(1989) Specification for ordinary Portland cement 43 grade

5. IS 383 (1970) Specification for coarse and fine aggregate

6. Bharathi V Subramania, J V Ramasamy, R Raghupathy C Seenivasan: Workability and strength study of high volume fly ash self-compacting concrete

7. EFNARC-Specifications and guidelines for Self Compacting Concrete: FEB-2002 